\title{
Addition of Hyaluronidase Reduces Failure of Regional Block in Ophthalmic Surgery: Meta-Analysis of Randomized Clinical Trials
}

\author{
Brennda Dolis Marretto de Moura ${ }^{1}$, Denismar Borges de Miranda ${ }^{2 *}$ and Catia Sousa Govêia ${ }^{3}$ \\ ${ }^{1}$ Anesthesiology Department of the Center for Studies and Training at the Dr. Jose Quinan, Goiânia, Goiás, Brazil \\ ${ }^{2}$ Physician of the Municipal Health Department of Goiânia, Goiás, Brazil \\ ${ }^{3}$ Anesthesiology Department of the Center for Studies and Training at the University of Brasília, Brasília, Distrito Federal, \\ Brazil \\ *Corresponding author: Denismar Borges de Miranda, PhD in Tropical Medicine and Public Health from the Institute of \\ Tropical Pathology and Public Health at the Federal University of Goiás. Physician at the Municipal Health Department of \\ Goiânia, Goiás, Brazil
}

\section{ARTICLE INFO}

Received: 彗 August 10, 2020

Published: 畿 August 21, 2020

Citation: Brennda Dolis Marretto de M, Denismar Borges de M and Catia Sousa G. Addition of Hyaluronidase Reduces Failure of Regional Block in Ophthalmic Surgery: Meta-Analysis of Randomized Clinical Trials. Biomed J Sci \& Tech Res 29(4)-2020. BJSTR. MS.ID.004838.

Keywords: Hyaluronoglucosaminidase; Anesthesia Conduction; Ophthalmologic Surgical Procedures; Meta-Analysis

Abbreviations: LA: Local Anesthetics; ASA: Physical Status Classification System; OR: Odds Ratio; 95\% CI: 95\% Confidence Interval; SD: Standard deviation; PB: Peribulbar Block; SB: Subtenoniano Block

\section{ABSTRACT}

Objetive: To evaluate the efficacy of hyaluronidase in preventing total/partial failure of regional block in ophthalmic surgery.

Method: Meta-analysis of randomized clinical trials, with patients undergoing ophthalmic procedures under peribulbar/subtenonian block, who received local anesthetic associated with hyaluronidase. The search for articles on PubMed used terms such as hyaluronidase, hyaluronoglucosaminidase and ophthalmology, or synonyms, using AND and OR interlocutors. Two independent researchers evaluated titles and abstracts. For those selected, there was complete reading of the text for inclusion in the sample. Manual search of references was also carried out. A random effects model (DerSimonian-Laird test) and Odds Ratios Calculation (OR) with 95\% confidence intervals (95\% CI) were used.

Results: 242 studies identified, 12 were selected, including 1,328 patients (689 cases and 639 controls). The use of hyaluronidase was considered a protective factor against ocular akinesia failure in regional anesthesia (OR: 0.55; 95\% CI: 0.32-0.93; p=0.027). The same was observed in the subgroups analysis with a hyaluronidase dose $>100 \mathrm{IU} / \mathrm{mL}$ (OR: $0.43 ; 95 \%$ CI: 0.20-0.90; $\mathrm{p}=0.02$ ) and association with bupivacaine (OR: 0.53; 95\% CI: 0.33-0.84; $\mathrm{p}=0.01$ ).

Conclusion: This meta-analysis shows the efficacy of hyaluronidase associated with local anesthetics in preventing regional block failure in ophthalmic surgery.

\section{Introduction}

Hyaluronidase is an enzyme that has been used as an adjunct to Local Anesthetics (LA) aiming to improve the speed of onset of blocks, dispersion, depth, better akinesia and analgesia. Its main action is depolymerization of extracellular hyaluronic acid, the intercellular cement of connective tissues, allowing anesthetic agents to spread more easily along the orbit through fine septal barriers of connective tissue [1]. When hyaluronidase is not used with local LA, increased concentrations of the anesthetic agent has the potential to accumulate around the extraocular muscles, leading to myotoxicity, increased orbital extracellular pressure and ischemic damage by decreasing blood flow in the branches of the ophthalmic artery [2]. The development of less invasive surgical techniques in ophthalmology has contributed to the replacement 
of general anesthesia by regional block techniques. Peribulbar (PB) and subtenonian blocks (SB) are commonly practiced, providing excellent conditions for operating the eye, but they have their inherent risks, such as eye perforation, hemorrhages, and even cardiorespiratory arrest, among others [3]. Less invasive techniques to provide local anesthesia, such as subconjunctival or topical application, present less risk of complications, but fail to provide adequate immobility [akinesia] of the eye and postoperative analgesia [3]. Among all LAs used in clinical practice, ropivacaine, bupivacaine, lidocaine and the association of bupivacaine and lidocaine stand out [4-6]. There is still no consensus on the efficacy and the most adequate dose of hyaluronidase in association with LA in ophthalmic blocks [7]. Thus, this meta-analysis aims to assess the effectiveness of hyaluronidase in preventing total or partial failure of regional block in ophthalmic surgery.

\section{Method}

Meta-analysis of randomized clinical trials that evaluated the efficacy of hyaluronidase associated with LA in preventing total or partial failure of PB or SB in patients undergoing eye surgery. The PRISMA Guidelines [8] were followed for the elaboration and reporting of a systematic review and meta-analysis of randomized clinical trials. Articles published up to April 2020 in the PubMed databases were selected using terms such as hyaluronidase, hyaluronoglucosaminidase and ophthalmology, or their synonyms, separated by AND and OR interlocutors. To complement the search, a manual analysis of the references of the studies that met the inclusion criteria was performed, aiming to identify original studies that were not previously found. Randomized, double-blind clinical trials with patients over 18 years old under eye surgery. Studies using retrobulbar block in animals, techniques combined with sedation, different comparison groups and unavailable full text were excluded.

Two independent researchers performed a preliminary assessment of the titles/abstracts and extracted the data. For those selected, there was a complete reading of the text, obeying the inclusion and exclusion criteria. In case of disagreement, a third researcher made the final assessment. The data referring to the patients were: age and physical status classification system (ASA), type and concentration of anesthetic agent used, association and dose of hyaluronidase, blocking technique, type of surgery, number of participants in each group, adverse events, akinesia or block failure (also accessed as need of supplementary doses), and classification of the methodological quality of the studies [9]. Regarding the studies that analyzed different doses of hyaluronidase in the same study, the effect of each dose compared to the control group was included, justifying the repetition of articles in the statistical analysis, differentiated by the letters (A) and (B). To explore sources of heterogeneity among studies, we planned sensitivity analysis by subgroups containing the same LA, LA concentration and/or association with hyaluronidase, doses of hyaluronidase greater than and less than $100 \mathrm{IU} / \mathrm{ml}$, and different blocking techniques (PB or SB). Statistical heterogeneity was calculated using the chi-square method $(\chi 2)$ and the Higgins test (I2) [10]. The odds ratio (OR) and a 95\% confidence interval (95\% CI) were used to assess the dichotomous variables differences between groups. The random effects model was adopted using the DerSimonian-Laird test [11] and statistical analysis using the Comprehensive Meta-analyzes ${ }^{\circledR}$ software v.3.3. Evaluation of potential publication bias was performed by visual analysis of the funnel graph and also Begg [12] and Egger [13] tests, adopting statistical significance of $5 \%$.

\section{Result}

Table 1: Description of selected studies

\begin{tabular}{|c|c|c|c|c|c|c|c|}
\hline Study year & Study details & Technician & $\mathbf{N}$ & Age Mean $\pm S D$ & ASA & Procedure & Jadad [12] \\
\hline $\begin{array}{c}\text { Crawford } 1994 \\
\text { [17] }\end{array}$ & $\begin{array}{c}\text { Lidocaína 2\%+Bupivacaína 0,75\% } \\
\text { Lidocaína 2\%+Bupivacaína } \\
\text { 0,75\%+Hialuronidase } 50 \mathrm{UI} / \mathrm{ml}\end{array}$ & $\mathrm{PB}$ & $\begin{array}{l}30 \\
30\end{array}$ & $\begin{array}{l}77 \\
75\end{array}$ & I - III & Intraocular & 3 \\
\hline $\begin{array}{l}\text { Brydon } 1995 \\
\text { (A) [18] }\end{array}$ & $\begin{array}{c}\text { Lidocaína 2\%+Bupivacaína 0,75\% } \\
\text { Lidocaína 2\%+Bupivacaína } \\
\text { 0,75\%+Hialuronidase 50UI/ml }\end{array}$ & $\mathrm{PB}$ & $\begin{array}{l}20 \\
20\end{array}$ & $\begin{array}{l}72 \pm 10.6 \\
74 \pm 10.4\end{array}$ & I - III & Intraocular & 3 \\
\hline $\begin{array}{c}\text { Brydon } 1995(\mathrm{~B}) \\
{[18]}\end{array}$ & $\begin{array}{c}\text { Lidocaína 2\%+Bupivacaína 0,75\% } \\
\text { Lidocaína 2\%+Bupivacaína } \\
\text { 0,75\%+Hialuronidase } 150 \mathrm{UI} / \mathrm{ml}\end{array}$ & $\mathrm{PB}$ & $\begin{array}{l}20 \\
20\end{array}$ & $\begin{array}{l}72 \pm 10.6 \\
73 \pm 11.0\end{array}$ & I - III & Intraocular & 3 \\
\hline $\begin{array}{c}\text { Prosser } 1996 \\
\text { [19] }\end{array}$ & $\begin{array}{c}\text { Lidocaína 2\%+Bupivacaína 0,5\% } \\
\text { Lidocaína 2\%+Bupivacaína } \\
\text { 0,5\%+Hialuronidase } 25 \mathrm{UI} / \mathrm{ml}\end{array}$ & $\mathrm{PB}$ & 2525 & $\begin{array}{l}59 \\
75\end{array}$ & I - IV & Cataract & 5 \\
\hline $\begin{array}{c}\text { Dempsey } \\
\text { 1997(A) [10] }\end{array}$ & $\begin{array}{c}\text { Lidocaína 2\%+Bupivacaína 0,5\% } \\
\text { Lidocaína 2\%+Bupivacaína } \\
\text { 0,5\%+Hialuronidase } 50 \mathrm{UI} / \mathrm{ml}\end{array}$ & $\mathrm{PB}$ & $\begin{array}{l}50 \\
75\end{array}$ & $\begin{array}{l}76 \\
75\end{array}$ & I - III & Intraocular & 3 \\
\hline $\begin{array}{c}\text { Dempsey } \\
\text { 1997(B) [10] }\end{array}$ & $\begin{array}{c}\text { Lidocaína 2\%+Bupivacaína 0,5\% } \\
\text { Lidocaína 2\%+Bupivacaína } \\
0,5 \%+\text { +Hialuronidase } 300 \mathrm{UI} / \mathrm{ml}\end{array}$ & $\mathrm{PB}$ & $\begin{array}{l}50 \\
75\end{array}$ & $\begin{array}{l}76 \\
76\end{array}$ & I - III & Intraocular & 3 \\
\hline
\end{tabular}




\begin{tabular}{|c|c|c|c|c|c|c|c|}
\hline $\begin{array}{l}\text { Bowman } 1997 \\
{[20]}\end{array}$ & $\begin{array}{c}\text { Lidocaína } 2 \% \text { com } \\
\text { adrenalina(1:200000)+ Bupivacaína } \\
0,5 \% \\
\text { Lidocaína } 2 \% \text { com } \\
\text { adrenalina(1:200000)+ Bupivacaína } \\
0,5 \%+\text { Hialuronidase } 150 \mathrm{UI} / \mathrm{ml}\end{array}$ & PB & $\begin{array}{l}48 \\
44\end{array}$ & $\begin{array}{l}72.0 \pm 11.5 \\
75.0 \pm 8.6\end{array}$ & --- & Intraocular & 4 \\
\hline Guise 1999 [21] & $\begin{array}{c}\text { Lidocaína 2\%+Bupivacaína0,5\% } \\
\text { Lidocaína 2\%+Bupivacaína } \\
\text { 0,5\%+Hialuronidase } 150 U \mathrm{UI}\end{array}$ & SB & $\begin{array}{l}60 \\
60\end{array}$ & $\begin{array}{l}70,9 \pm 10.0 \\
73,4 \pm 10.4\end{array}$ & --- & Cataract & 3 \\
\hline $\begin{array}{l}\text { Rowley } 2000 \\
{[22]}\end{array}$ & $\begin{array}{c}\text { Lidocaína 2\%+adrenalina(1:200000) } \\
\text { Lidocaína 2\%+adrenalina(1:200000)+ } \\
\text { Hialuronidase } 30 \mathrm{UI} / \mathrm{ml}\end{array}$ & SB & $\begin{array}{l}76 \\
74\end{array}$ & $\begin{array}{l}77.14 \\
76.51\end{array}$ & --- & Cataract & 5 \\
\hline $\begin{array}{l}\text { Mantovani } \\
\text { 2001(A) [23] }\end{array}$ & $\begin{array}{c}\text { Lidocaína 2\%+Ropivacaína 1\% } \\
\text { Lidocaína 2\%+Ropivacaína } \\
\text { 1\%+Hialuronidase 15UI/ml }\end{array}$ & PB & $\begin{array}{l}30 \\
31\end{array}$ & $\begin{array}{l}73 \\
71\end{array}$ & --- & Cataract & 5 \\
\hline $\begin{array}{l}\text { Mantovani } \\
\text { 2001(B) [23] }\end{array}$ & $\begin{array}{c}\text { Lidocaína 2\%+Ropivacaína 1\% } \\
\text { Lidocaína 2\%+Ropivacaína } \\
\text { 1\%+Hialuronidase } 150 \text { UI/ml }\end{array}$ & PB & $\begin{array}{l}30 \\
29\end{array}$ & $\begin{array}{l}73 \\
74\end{array}$ & --- & Cataract & 5 \\
\hline $\begin{array}{c}\text { Alwitry } 2002 \\
{[24]}\end{array}$ & $\begin{array}{c}\text { Lidocaína2\% } \\
\text { Lidocaína2\%+Hialuronidase 150UI/ml }\end{array}$ & SB & $\begin{array}{l}48 \\
52\end{array}$ & $\begin{array}{c}75 \pm 10.11 \\
77 \pm 7.64\end{array}$ & --- & Cataract & 4 \\
\hline $\begin{array}{l}\text { Schulenburg } \\
2007[25]\end{array}$ & $\begin{array}{c}\text { Lidocaína2\% } \\
\text { Lidocaína2\%+Hialuronidase 15UI/ml }\end{array}$ & SB & $\begin{array}{l}31 \\
31\end{array}$ & $\begin{array}{l}77 \\
69\end{array}$ & I - III & Cataract & 5 \\
\hline $\begin{array}{l}\text { Sedghipour } \\
2012 \text { [7] }\end{array}$ & $\begin{array}{c}\text { Lidocaína2\% } \\
\text { Lidocaína2\%+Hialuronidase 150UI/ml }\end{array}$ & SB & $\begin{array}{l}21 \\
21\end{array}$ & --- & --- & Cataract & 5 \\
\hline $\begin{array}{l}\text { Swathi } 2018 \\
\text { [26] }\end{array}$ & $\begin{array}{c}\text { Lidocaína 2\%+Bupivacaína 0,5\% } \\
\text { Lidocaína 2\%+Bupivacaína } \\
\text { 0,5\%+Hialuronidase } 50 \mathrm{UI} / \mathrm{ml}\end{array}$ & $\mathrm{PB}$ & $\begin{array}{l}100 \\
102\end{array}$ & $\begin{array}{c}58,6 \pm 9.08 \\
58,4 \pm 9.6\end{array}$ & --- & Cataract & 5 \\
\hline Total & & & 1,328 & & & & \\
\hline
\end{tabular}

Note: SD: Standard deviation; PB: peribulbar block; SB: subtenoniano block; ASA: Physical Status Classification System

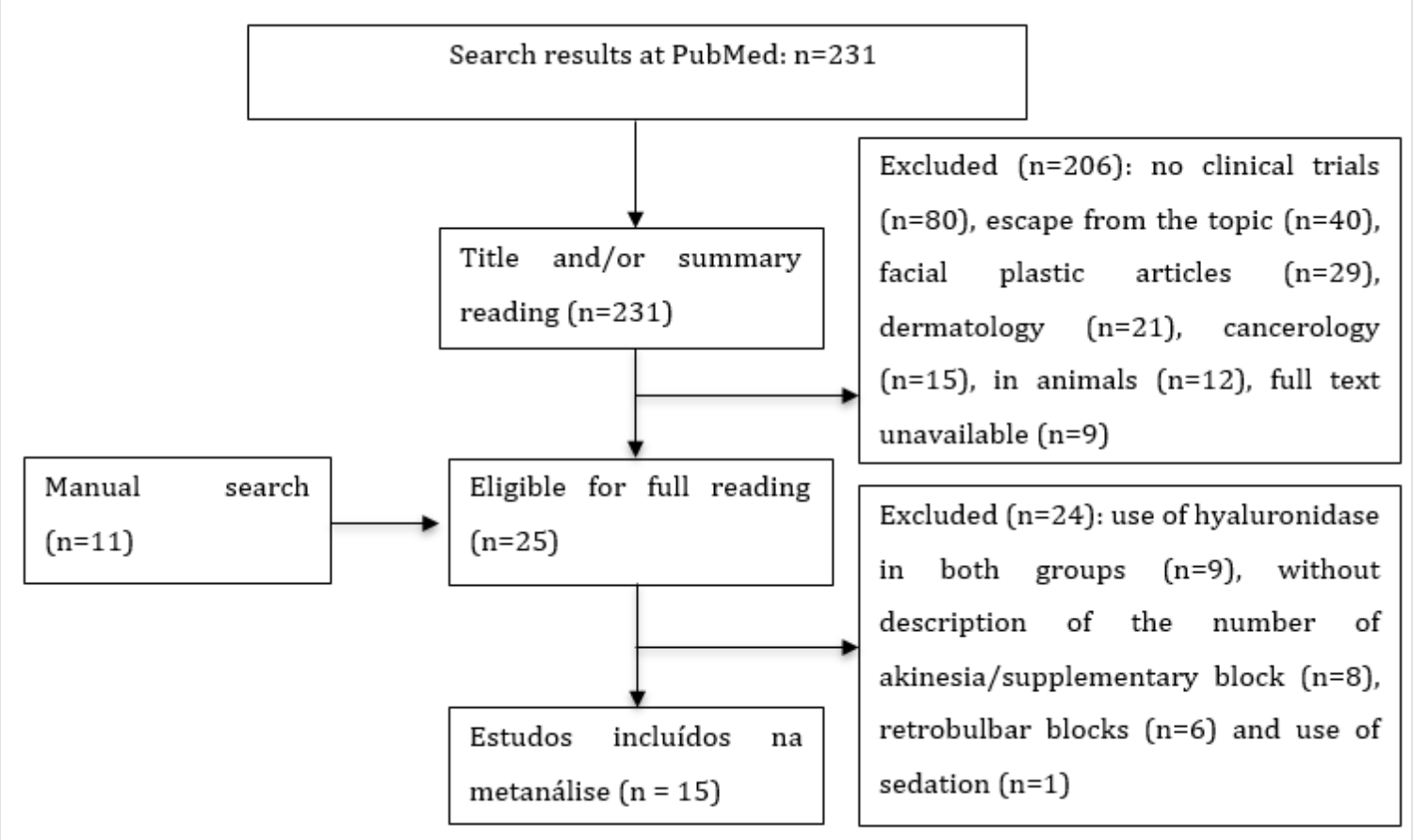

Figure 1: Diagram of selected studies. 
To compose this meta-analysis, 242 studies were identified (231 studies in the database and 11 by manual search), 12 of which were selected [7,14,15-24]. All were published between 1994 and 2018, as shown in Figure 1. When defining that the different doses of hyaluronidase should be included in this study, publications that used two different dosages were doubly cited (A) and (B). Thus, the initial 12 studies [7,14,15-24] became 15 sources of information, accounting for 1,328 patients, 689 in the hyaluronidase group and 639 in the control group, with their characteristics shown in
Table 1. Six studies were carried out in England [7,18,20-23], two in Scotland [15,16], and the others in Iran [14] Wales [17], New Zealand [19] and India [24]. The use of hyaluronidase, evaluated in the 15 studies sources [7,14,15-24] regardless of the type and concentration of LA, hyaluronidase dose and regional blocking technique, was considered a protective factor against ocular akinesia failure in ophthalmic surgery (OR: 0.55; 95\% CI: 0.32-0.93; $\mathrm{p}=0.027$ ), as shown in Figure 2 .

$\begin{array}{lc}\text { Study } & \begin{array}{c}\text { Hyaluronidase } \\ \text { (n/N) }\end{array} \\ \text { Crawford 1994 [17] } & 1 / 30 \\ \text { Brydon 1995(A) [18] } & 13 / 20 \\ \text { Brydon 1995(B) [18] } & 10 / 20 \\ \text { Prosser 1996[19] } & 9 / 25 \\ \text { Dempsey 1997(A) [10] } & 49 / 75 \\ \text { Dempsey 1997(B) [10] } & 45 / 75 \\ \text { Bowman 1997 [20] } & 18 / 44 \\ \text { Guise 1999 [21] } & 4 / 60 \\ \text { Rowley 2000 [22] } & 34 / 74 \\ \text { Mantovani 2001(A) [23] } & 9 / 31 \\ \text { Mantovani 2001(B) [23] } & 4 / 29 \\ \text { Alwitry 2002 [24] } & 0 / 52 \\ \text { Schulenburg 2007 [25] } & 7 / 31 \\ \text { Sedghipour 2012 [7] } & 14 / 21 \\ \text { Swathi 2018 [26] } & 5 / 102 \\ \text { Total } & 222 / 689 \\ & \end{array}$

Heterogeneity test: $\mathrm{X} 2=38.47 ; \mathrm{GL}=14(\mathrm{p}=0.000) ; \mathrm{I} 2=63.61 \%$

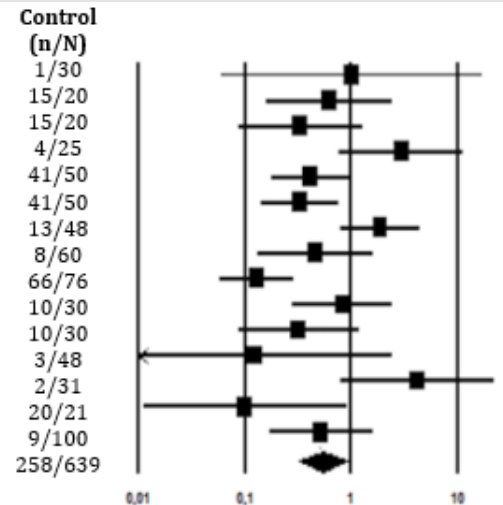

\begin{tabular}{cl}
$\begin{array}{c}\text { Weight } \\
\text { (\%) }\end{array}$ & \multicolumn{1}{c}{$\begin{array}{c}\text { Random effects } \\
\text { OR (IC 95\%) }\end{array}$} \\
2.76 & $1.00(0.06 ; 16.76)$ \\
6.61 & $0.62(0.16 ; 2.43)$ \\
6.72 & $0.33(0.09 ; 1.27)$ \\
6.70 & $2.95(0.77 ; 11.34)$ \\
8.90 & $0.41(0.17 ; 0.98)$ \\
8.93 & $0.33(0.14 ; 0.78)$ \\
8.84 & $1.86(0.78 ; 4.47)$ \\
7.07 & $0.46(0.13 ; 1.63)$ \\
9.17 & $0.13(0.06 ; 0.29)$ \\
7.85 & $0.82(0.28 ; 2.42)$ \\
6.89 & $0.32(0.09 ; 1.17)$ \\
2.52 & $0.12(0.01 ; 2.46)$ \\
5.48 & $4.23(0.80 ; 22.29)$ \\
3.92 & $0.10(0.01 ; 0.91)$ \\
7.64 & $0.52(0.17 ; 1.61)$ \\
100 & $0.55(0.32 ; 0.93)$
\end{tabular}

Overall effect test: $\mathrm{Z}=-2.213(\mathrm{p}=0.027)$

Figure 2: Meta-analysis of the evaluation of akinesia failure in ophthalmic block with hyaluronidase compared with control, regardless of the concentration and technique of the block.

$\begin{array}{lcc}\text { Study } & \begin{array}{c}\text { Hyaluronidase } \\ (\mathbf{n} / \mathbf{N})\end{array} & \begin{array}{c}\text { Control } \\ \text { (n/N) }\end{array} \\ \text { Brydon 1995(B) [18] } & 10 / 20 & 15 / 20 \\ \text { Dempsey 1997(B) [10] } & 45 / 75 & 41 / 50 \\ \text { Bowman 1997 [20] } & 18 / 44 & 13 / 48 \\ \text { Guise 1999 [21] } & 4 / 60 & 8 / 60 \\ \text { Mantovani 2001(B) [23] } & 4 / 29 & 10 / 30 \\ \text { Alwitry 2002 [24] } & 0 / 52 & 3 / 48 \\ \text { Sedghipour 2012 [7] } & 14 / 21 & 20 / 21 \\ \text { Total } & 95 / 301 & 110 / 277\end{array}$

$$
\begin{gathered}
\text { Heterogeneity test: } \\
\mathrm{X}^{2}=13.28 ; \mathrm{GL}=6(\mathrm{p}=0.039) ; \mathrm{I}^{2}=54.83 \%
\end{gathered}
$$

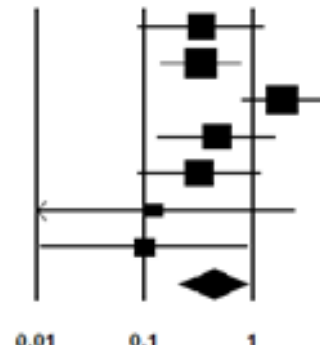

0,1
Favors hyaluronidase

\begin{tabular}{|c|c|}
\hline $\begin{array}{l}\text { Weight } \\
(\%)\end{array}$ & $\begin{array}{c}\text { Random effects } \\
\text { OR (IC } 95 \% \text { ) }\end{array}$ \\
\hline 14.80 & $0.33(0.09-1.27)$ \\
\hline 20.69 & $0.33(0.14-0.78)$ \\
\hline 20.44 & $1.86(0.78-4.47)$ \\
\hline 15.68 & $0.46(0.13-1.63)$ \\
\hline 15.22 & $0.32(0.09-1.17)$ \\
\hline 5.06 & $0.12(0.01-2.46)$ \\
\hline 8.11 & $0.10(0.01-0.91)$ \\
\hline 100 & $0.43(0.20-0.90)$ \\
\hline
\end{tabular}

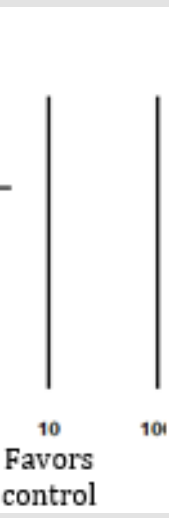

Overall effect test: $\mathrm{Z}=-2.25(\mathrm{p}=0.02)$

Figure 3: Meta-analysis of the evaluation of akinesia failure in ophthalmic block with hyaluronidase at doses greater than $100 \mathrm{IU} / \mathrm{mL}$ compared to the control group, regardless of the concentration of local anesthetic.

Subgroup analysis were performed to reduce potential biases, which could hinder final data reasoning. In the sub-analysis by block techniques, regardless of the type and concentration of LA and dose of hyaluronidase, there was no statistically significant difference between the groups of hyaluronidase and control, either for SB (5 studies [14,19,20,22,23]; OR: 0.34; 95\% CI: 0.09-1.34; $\mathrm{p}=0.12$ ) or in PB (10 studies [7,15-28,21,24]; OR: 0.65; 95\% CI: 0.40-1.07; $\mathrm{p}=0.09$ ). Still on the hyaluronidase dose, regardless of the type and concentration of LA and the regional blocking technique, the use of a dose greater than $100 \mathrm{IU} / \mathrm{mL}$ was considered a protective factor, as it prevented akinesia failure in ophthalmic anesthesia (7 studies
[7,14,16,18,19,21,22]; OR: 0.43; 95\% CI: 0.20-0.90; p=0.02) (Figure $3)$. However, there was no difference for the use of a dose lower than $100 \mathrm{IU} / \mathrm{mL}$ (8 studies [7,15-17,20,21,23,24]; OR: 0.70; 95\% CI: $0.31-1.60 ; p=0.40)$. In the comparison by type of association of LA, using lidocaine plus bupivacaine in both groups, aside from of LA concentration, hyaluronidase dose and blocking technique, the presence of hyaluronidase was considered a protective factor in order to avoid failure of ocular akinesia in regional anesthesia (8 studies [7,15-17,29,24]; OR: 0.53; 95\% CI: 0.33-0.84; p=0.01) (Figure 4). Conversely, the use of lidocaine as sole LA, regardless of the dose of hyaluronidase, produced no difference between the 
group of hyaluronidase and the control group (3 studies [14,22,23]; OR: 0,43; 95\% CI: 0, 03-6.47; p=0.54). All the included studies reported the occurrence of adverse events. However, there was no statistically significant difference between the groups. The visual evaluation of the funnel graph (Figure 5), including all the articles that comprise this meta-analysis, as well as the analysis of the Begg $(p=0.657)$ and Egger $(p=0.663)$ tests, do not suggest publication bias.

$\begin{array}{lcc}\text { Study } & \begin{array}{c}\text { Hyaluronidase } \\ (\mathbf{n} / \mathbf{N})\end{array} & \begin{array}{c}\text { Control } \\ (\mathbf{n} / \mathbf{N})\end{array} \\ \text { Crawford 1994 [17] } & 1 / 30 & 1 / 30 \\ \text { Brydon 1995(A) [18] } & 13 / 20 & 15 / 20 \\ \text { Brydon 1995(B) [18] } & 10 / 20 & 15 / 20 \\ \text { Prosser 1996 [19] } & 9 / 25 & 4 / 25 \\ \text { Dempsey 1997(A) [10] } & 49 / 75 & 41 / 50 \\ \text { Dempsey 1997(B) [10] } & 45 / 75 & 41 / 50 \\ \text { Guise 1999 [21] } & 4 / 60 & 8 / 60 \\ \text { Swathi 2018 [26] } & 5 / 102 & 9 / 100 \\ \text { Total } & 136 / 407 & 134 / 355\end{array}$

Heterogeneity test: $\mathrm{X}^{2}=8.48 ; \mathrm{GL}=7(\mathrm{p}=0.29) ; \mathrm{I}^{2}=17.44 \%$

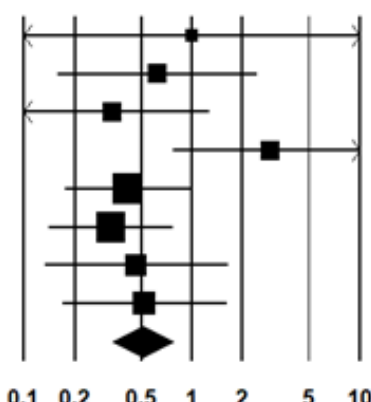

Favors hyaluronidase

$\begin{array}{cl}\begin{array}{c}\text { Weight } \\ \text { (\%) }\end{array} & \begin{array}{c}\text { Random effects } \\ \text { OR (IC 95\%) }\end{array} \\ 2.62 & 1.00(0.06 ; 16.76) \\ 9.98 & 0.62(0.16 ; 2.43) \\ 10.34 & 0.33(0.09 ; 1.27) \\ 10.25 & 2.95(0.77 ; 11.34) \\ 20.67 & 0.41(0.17 ; 0.98) \\ 20.93 & 0.33(0.14 ; 0.78) \\ 11.49 & 0.46(0.13 ; 1.63) \\ 13.72 & 0.52(0.17 ; 1.61) \\ 100 & 0.53(0.33 ; 0.84)\end{array}$

Overall effect test: $\mathrm{Z}=-2.71(\mathrm{p}=0.01)$

Figure 4: Meta-analysis of the evaluation of akinesia failure in ophthalmic block, with the association of bupivacaine in both groups, regardless of dose, hyaluronidase concentration and block technique.

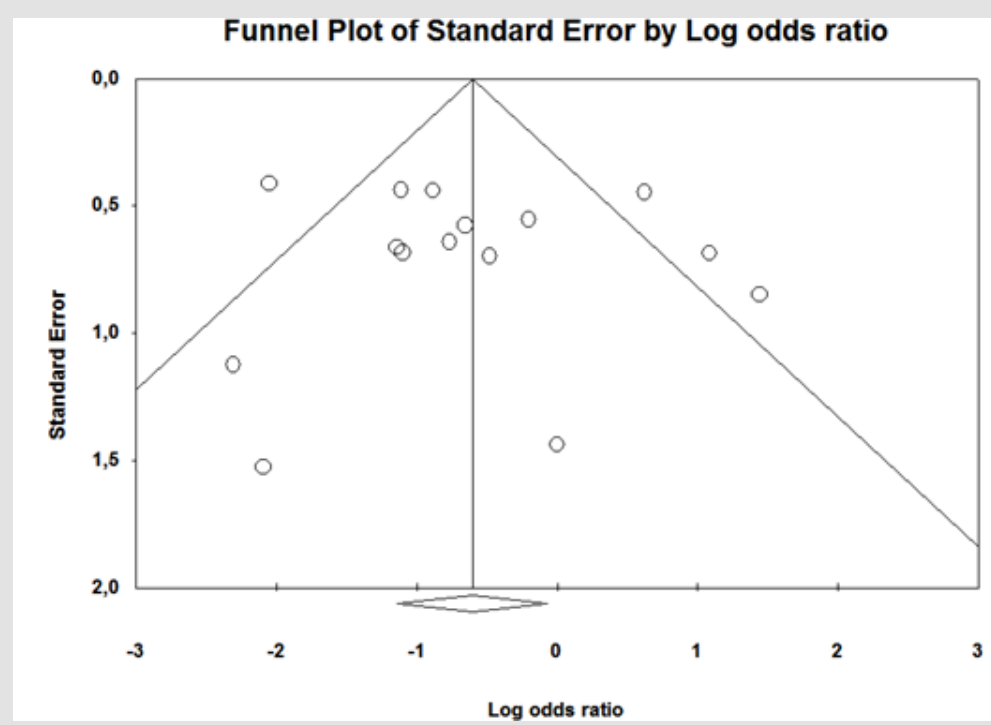

Figure 5: Funnel plot of the evaluation of akinesia failure in ophthalmic block with hyaluronidase compared to control, regardless of AL concentration, hyaluronidase dose and regional block technique.

\section{Discussion}

This meta-analysis consists of 12 randomized clinical trials [7,14,15-24], published until April 2020, which evaluated the effectiveness of hyaluronidase in preventing total/partial failure of the $\mathrm{PB} / \mathrm{SB}$ in ophthalmic surgery. Hyaluronidase proved to be effective in preventing blockage failure in ophthalmic anesthesia. With the techniques used, satisfactory ocular akinesia was obtained and adverse events were minimal, even in different concentrations of added LA. Hyaluronidase has been used for many decades as an adjunct to the local anesthetic solution, aiming to improve the speed of onset of regional blocks in ophthalmic surgeries and to provide better akinesia and analgesia [1]. Reaffirming this thesis, a study proved, by means of ultrasound, that the addition of hyaluronidase results in faster dispersion of LA [3]. Another benefit of hyaluronidase is to change the $\mathrm{pH}$ of the solution due to the presence of phosphate buffers in the preparation. The $\mathrm{pH}$ of the bupivacaine solution changes from 5.3 to 6.3 after the addition of hyaluronidase and can maintain the solubility of AL during the alkalinization process, generating less pain on application [25]. Studies that evaluate the dose of hyaluronidase in ophthalmic anesthesia are conflicting, with no consensus on the effective dose. This makes it difficult to standardize the enzyme's use and 
reduces adherence to its adoption [21]. On the group that used a hyaluronidase dose greater than $100 \mathrm{IU} / \mathrm{mL}$, its presence behaved as a protective factor against block failure. The main hypotheses for this are due to the fact that there is a dose-dependent effect, which facilitates the dispersion of LA and a consequent decrease in the failure rate [1].

When the two subgroups of LA type were analyzed, the studies that used sole bupivacaine comparing the presence or absence of hyaluronidase versus the studies that used only lidocaine in the presence or absence of hyaluronidase, the reduction in the block failure could only be found in the association containing the bupivacaine. This may be possibly due to the pharmacokinetic and pharmacodynamic properties of bupivacaine [6,26]. Since it is more potent and has a longer duration of action, it promotes absent eye movement for a longer time compared to lidocaine. This finding is consistent with the results of other studies $[6,26]$. On the other hand, a disadvantage of bupivacaine relies in its more evident cardiotoxicity than lidocaine [27]. Lidocaine has a pKa closer to the physiological one, which implies shorter latency, faster onset of action, but also shorter duration, with the need to repeat supplementary doses, including intraoperatively $[6,28]$. This, in theory, can justify the non-association shown in this meta-analysis. Another possibility would be the small number of studies that used lidocaine.

Some data require close attention in this study. Due to the fact that there is no uniform and standardized method for assessing akinesia, a wide variety of different scales were used, all subjective and open to the observer's error [3]. Thus, in order to standardize the assessment of akinesia, a specific time point cited in all articles was considered. After 15 minutes, all patients were reevaluated, either reached "satisfactory" akinesia (absence of movement in the quadrants of vision) or required re-blocking with supplementary doses. Only five articles $[15,17,20,21,23]$ reported the "degree of akinesia". Therefore, the failure of akinesia had to be inferred when there was need to re-block with a supplementary dose. An important point reported in one of the selected clinical trials was that, when considering the quality of the block at 13 minutes, no significant difference was found between the groups [19], however, in this meta-analysis the opposite was shown: at 15 minutes, there were differences between the group that used hyaluronidase and the control group, endorsing the protective effect of the use of hyaluronidase in the anesthetic solution, capable of preventing the failure of ophthalmic block.

There were minimal reports of adverse events among the studies, and no statistical significance difference when comparing hyaluronidase and control groups. It is noteworthy that the literature indicates that other factors are more strongly associated with adverse events, such as blocking techniques, myotoxicity of accumulated LA, types of needle and punctures, more than one puncture, total volume used [29]. An adequate meta-analysis should include relevant studies, of low heterogeneity and detect potential biases [8]. Despite the different strategies adopted in this study to minimize possible biases, such as analysis by subgroups, those cannot be ruled out. Double-blind, randomized clinical studies were included, but the search was performed in only one database, which in fact did not compromise the result since we did not find publication bias in the Begg [12] and Egger [13] tests. The inclusion of different doses of hyaluronidase, types and concentrations of LA and varied regional blocking technique, corroborated for the presence of clinical heterogeneity in the studies that justified the use of the random effects model. No studies were found to describe the economic impact of hyaluronidase use. In the current climate of financial constraints, this information would be very valuable, and any future study must incorporate this aspect.

\section{Conclusion}

This meta-analysis shows the efficacy of hyaluronidase associated with local anesthetics in preventing failure of regional block in ophthalmic surgery.

\section{Conflict of Interest}

The authors have declared that no competing interest exists.

\section{Author's Contribution}

BDMM, DBM and CSG worked on the conception and design of the research, the analysis and interpretation of data, the writing of the article and the approval of the version to be published.

\section{References}

1. Horliana ACRT (2006) Avaliação da duração anestésica sob influência da hialuronidase injetada isoladamente no bloqueio pterygomandibular [thesis]. São Paulo: Universidade de São Paulo.

2. Jehan FS, Hagan JC, Whittaker TJ, Subramanian M (2001) Diplopia and ptosis following injection of local anesthesia without hyaluronidase. J Cataract Refract Surg 27(11):1876-1879.

3. Khandwala M, Ahmed S, Goel S, Simmons IG, McLure HA (2008) The effect of hyaluronidase on ultrasound-measured dispersal of local anaesthetic following sub-tenon injection. Eye 22(8): 1065-1068.

4. Seidenari P, Santin G, Milani P, David A (2010) Peribulbar and retrobulbar combined anesthesia for vitreoretinal surgery using ropivacaine. Eur J Ophthalmol 16(2): 295-299.

5. Jaworski J, Jałowiecki P, Marciniak R, Rudner R, Wartak M (2006) Ropivacaine vs lidocaine/bupivacaine and lidocaine/ropivacaine mixtures for peribulbar block in cataract surgery. Anestezjol Intens Ter 38(4): 180-183.

6. Borazan M, Karalezli A, Oto S, Algan C, Akova YA (2007) Comparison of a bupivacaine $0.5 \%$ and lidocaine $2 \%$ mixture with levobupivacaine $0.75 \%$ and ropivacaine $1 \%$ in peribulbar anaesthesia for cataract surgery with phacoemulsification. Acta Ophthalmol Scand 85(8): 844-847.

7. Dempsey GA, Barrett PJ, Kirby IJ (1997) Hyaluronidase and peribulbar block. Br J Anaesth 78(6): 671-674.

8. Moher D, Liberati A, Tetzlaff J, Altman DG (2009) Preferred reporting items for systematic reviews and meta-analyses: the PRISMA statement. Ann Intern Med 151(4): 264-269. 
9. Jadad AR, Moore RA, Carroll D, Jenkinson C, Reynolds DJ, et al. (1996) Assessing the quality of reports of randomized clinical trials: is blinding necessary? Control Clin Trials 17(1): 1-12.

10. Higgins JPT, Thompson SG (2002) Quantifying heterogeneity in a metaanalysis. Stat Med 21(11): 1539-1558.

11. DerSimonian R, Laird N (1986) Meta-analysis in clinical trials. Control Clin Trials 7: 177-188.

12. Begg CB, Mazumdar M (1994) Operating characteristics of a rank correlation test for publication bias. Biometrics 50(4):1088-1101.

13. Egger M, Smith GD, Schneider M, Minder C (1997) Bias in meta-analysis detected by a simple, graphical test. BMJ 315(7109): 629-634.

14. Sedghipour M, Mahdavifard A, Fouladi RF, Gharabaghi D, Rahbani M, et al. (2012) Hyaluronidase in sub-tenon's anesthesia for phacoemulsification, a double-blind randomized clinical trial. Int J Ophthalmol 5(3): 389-392.

15. Crawford M, Kerr WJ (1994) The effect of hyaluronidase on peribulbar block. Anaesthesia 49(10): 90788.

16. Brydon CW, Basler M, Kerr WJ (1995) An evaluation of two concentrations of hyaluronidase for supplementation of peribulbar anaesthesia. Anaesthesia 50(11): 998-1000.

17. Prosser DP, Rodney GE, Mian T, Jones HM, Khan MY (1996) Re-evaluation of hyaluronidase in peribulbar anaesthesia. Br J Ophthalmol 80(9): 827830.

18. Bowman RJC, Newman DK, Richardson EC, Callear AB, Flanagan DW (1997) Is hyaluronidase helpful for peribulbar anaesthesia? Eye 11(3): 385-388.

19. Guise P, Laurent S (1999) Sub-tenon's block: the effect of hyaluronidase on speed of onset and block quality. Anaesth Intensive Care 27(2): 179181.

\section{ISSN: 2574-1241}

DOI: $10.26717 /$ BJSTR.2020.29.004838

Denismar Borges de Miranda. Biomed J Sci \& Tech Res

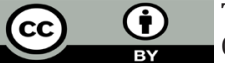

This work is licensed under Creative Commons Attribution 4.0 License

Submission Link: https://biomedres.us/submit-manuscript.php
20. Rowley SA, Hale JE, Finlay RD (2000) Sub-Tenon's local anaesthesia: the effect of hyaluronidase. Br J Ophthalmol 84(4): 435-436.

21. Mantovani C, Bryant AE, Nicholson G (2001) Efficacy of varying concentrations of hyaluronidase in peribulbar anaesthesia. Br J Anaesth 86(6): 876-878.

22. Alwitry A, Chaudhary S, Gopee K, Butler TK, Holden R (2002) Effect of hyaluronidase on ocular motility in sub-tenon's anesthesia. J Cataract Refract Surg 28(8):1420-1423.

23. Schulenburg HE, Sri-Chandana C, Lyons G, Columb MO, McLure HA (2007) Hyaluronidase reduces local anaesthetic volumes for sub-tenon's anaesthesia. Br J Anaesth 99(5): 717-720.

24. Swathi N, Srikanth K, Venipriya S (2018) Does the addition of hyaluronidase improve the quality of peribulbar anesthesia in cataract surgery? a randomized double blinded study. Saudi J Ophthalmol 32(3): 204-210.

25. Roberts J, MacLeod B, Hollands RH (1993) Improved peribulbar anaesthesia with alkalinization and hyaluronidase. Can J Anaesth 40(9): 835-838.

26. Chin GN, Almquist HT (1983) Bupivacaine and lidocaine retrobulbar anesthesia: a double-blind clinical study. Ophthalmology 90(4): 369372.

27. Almeida GPA, Boos GL, Alencar TG, Oliveira Filho GR (2005) Latência da lidocaína a 1\% para anestesia infiltrativa da pele. Rev Bras Anestesiol 55: 284-288.

28. Fróis AC, Leão BCC, Tavares ARC (2015) Choice of local anesthetic for peribulbar block: literature review. Rev Med Minas Gerais 25(Supl 4): 21-27.

29. Sarvela J, Nikki P (1992) Hyaluronidase improves regional ophthalmic anaesthesia with etidocaine. Can J Anaesth 39(9): 920-924.

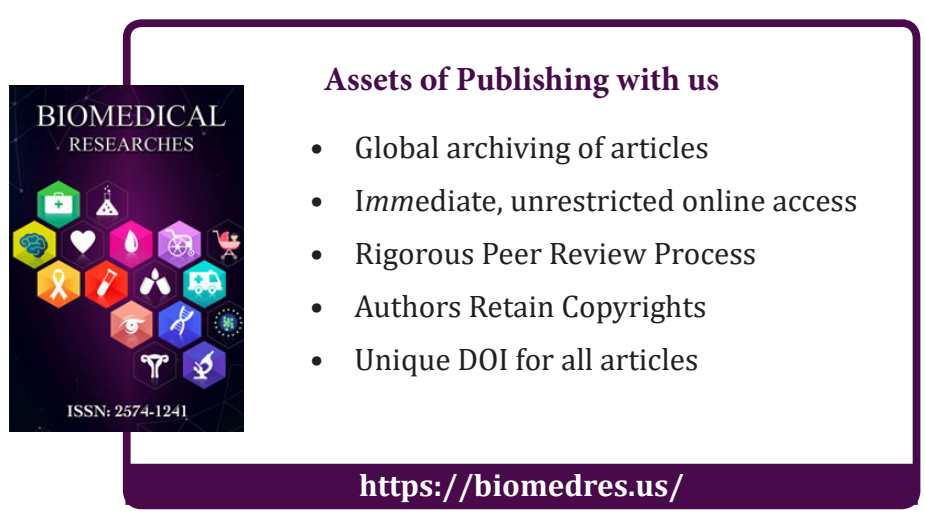

